\title{
Lapurdum
}

Euskal ikerketen aldizkaria | Revue d'études basques |

Revista de estudios vascos | Basque studies review

19 | 2016

Numéro XIX

\section{Bizkaiko euskaldun gazteen N/Z galderen ezaugarriez eta bariazioaz}

Iñaki Gaminde

\section{OpenEdition}

\section{Journals}

Édition électronique

URL : https://journals.openedition.org/lapurdum/3354

DOI : 10.4000/lapurdum.3354

ISSN : 1965-0655

\section{Éditeur}

IKER

Édition imprimée

Date de publication : 1 janvier 2016

Pagination : 271-281

ISBN : 978-2-95534-134-6

ISSN : 1273-3830

Référence électronique

Iñaki Gaminde, «Bizkaiko euskaldun gazteen N/Z galderen ezaugarriez eta bariazioaz», Lapurdum [Linean], 19 | 2016, Sarean emana----an 01 janvier 2021, kontsultatu 03 septembre 2021. URL: http:// journals.openedition.org/lapurdum/3354 ; DOI: https://doi.org/10.4000/lapurdum.3354 


\section{Bizkaiko euskaldun gazteen N/Z galderen ezaugarriez eta bariazioaz}

Iñaki GAMINDE

UPV-EHU

\section{Laburpena}

Lan honen helburua bikoitza da. Batetik, Bizkaiko euskaldun gazteek erabiltzen dituzten N/Z galderen deskripzio fonologikoa egiten da eta, bestetik, bariazioaren azterketa. Gure azterketa fonologikoa esaldien kurben azterketa fonetikoan oinarritzen da. Aldeak esaldiaren amaieran gertatzen direnez gero, hiru muga-tonu proposatzen ditugu: L\%, H\% eta LH\%. Bariazioaren azterketa aldagai diafasikoak eta diastratikoak kontuan hartuta egin dugu. Lehenengoetan esaldiak egiteko erabili diren hizkera estiloak kontuan hartu dira, hau da, bat-bateko esaldiak eta esaldi irakurriak; eta bigarrengoetan informatzaileen ama hizkuntza eta generoa.

Hitz giltzak: Intonazioa, fonologia, bariazio diafasikoa, bariazio diastratikoa.

\section{Sarrera ${ }^{1}$}

Geroago ugariagoak dira aspaldiko urteotan euskararen intonazioaren gainean egiten diren lanak, dela barietate batzuen deskripzioak egiten direlako (Uriarte, 1995; Gandarias, 1996; Elordieta, 1997, 1999, 2000; Jun eta Elordieta, 1997; Legarra 2011; Gaminde eta lag. 2012, besteak beste), dela lan orokorragoak egiten direlako (Elordieta, 2003, 2008; Gaminde eta lag. 2014).

Era berean hizkuntzaren bariazioa aztertzen dituzten lanetan ere, intonazioari bere lekua ematen hasi zaio (Aurrekoetxea eta Gaminde, 2011; Aurrekoetxea eta lag. 2011, Gaminde eta lag. 2014).

1. Ikerketa hau UPV/EHUko GIU13-23 ikerketa proiektuaren laguntzari esker burutu da. 
Gure kasu honetan N/Z galderak hartu ditugu aztergaitzat. N/Z galderak galdetzaile baten bidez egiten direnak dira eta orain arte (Gaminde, 2007, 2010; Gaminde eta lag. 2014) erakutsi den moduan, esaldi osoaren gailur prosodikoa galdetzailean bertan kokatuta edukitzen dute. Aldea esaldiaren amaieran sortzen da, izan ere, esaldiaren muga-tonua ez da kasu guztietan bat bera izaten (Gaminde, 2010).

Intonazioa kontuan hartzen duten bariazio azterketek inbentario eta arau fonologikoetan oinarritu behar dira, hau da, erkagarriak diren azentu tonudunak, sintagma tonuak eta mugatonuak erabili behar dituzte erkaketak egin ahal izateko. Hala ere, intonazioaren kasuan uste dugu azterketa fonologikoak azterketa fonetikoen emaitzetan oinarritu behar direla. Lan honetan erakutsiko dugun moduan, kurbaren azterketa fonetikoa kontuan hartu ezik mugatonuetan gertatzen diren ñabardura batzuk ez lirateke aintzat edukiko.

Gure lantxo honen helburua bikoitza da; batetik Bizkaiko gazte euskaldunen N/Z galdera moten azterketa fonologikoa aurkeztuko dugu eta, bestetik, N/Z galderetan dagoen bariazioaren azterketa aurkeztuko dugu aldagai diastratiko biren arabera (informatzaileen generoa eta ama hizkuntza) eta aldagai diafasiko baten arabera (hizkera estiloa).

Bariazio diastratikoa aztertzeko hizkera estilo bi landuko ditugu; batetik, bat-bateko esaldiak aztertuko ditugu eta, bestetik, esaldi irakurriak. Hainbat lanetan nabarmendu da irakurketa ozenaren garrantzia (Gaminde eta Goikoetxea, 2005; Gaminde eta lag. 2014), horregatik bariazio diastratikoaren azterketan faktore hau aztertu nahi izan dugu balizko aldeak agirian jartzeko.

Lana bost ataletan banatuta aurkezten dugu. Sarrera honen osteko bigarren atalean datuak jasotzeko erabili dugun metodologia aurkeztuko dugu. Hirugarren atalean datuen azterketa fonologikoaren emaitzak emango ditugu. Laugarren atalean aukeratu ditugun aldagaien araberako bariazioaren azterketa azalduko da. Azkenik, bosgarren atalean, ondorio nagusiak laburbilduko ditugu.

\section{Metodologia}

Datuak jasotzeko metodo bi erabili dira; batetik, bat-bateko esaldiak jasotzeko, beren beregi prestatutako galdekizun batzuk erabili dira eta informatzaileei eskatu zitzaien esaldia itzultzeko bakoitzak bere barietatearen arabera. Kasu guztietan itzulpena bi aldiz egin behar izan dute (atal honetan datu iturri bi erabili dira GIU13-23 ikerketa proiekturako batutako datuak eta lan honen egilearen artxiboa). Bestetik, euskara estandarrean idatzitako esaldi bilduma bat aurkeztu zitzaien informatzaileei zeuden moduan ozenki irakurtzeko, esaldi bakoitza hiru aldiz irakurri behar izan dute.

Corpusa 133 esaldik osatzen dute (informatzaile bakoitzeko esaldi bat). Esaldi horietako $101(\% 75,94)$ bat-batekoak izan dira eta $32(\% 24,06)$ irakurriak.

Denetara 133 informatzaile izan ditugu, 101 bat-bateko esaldiak jasotzeko eta 32 esaldi irakurriak jasotzeko. Informatzaileak neskak eta mutilak izan dira, 18-27 urte bitartekoak, denek ikasketak D ereduan burutu dituzte eta gehienak unibertsitateko ikasleak izan dira inkestak burutzean. Euron ama hizkuntzari dagokionez, talde bi egin daitezke; batean, euron ama hizkuntzatzat euskararen barietate tradizionalen bat etxean jaso dutenak ditugu (A taldea) eta, bestean, euskara txikitan hezkuntza sistemaren bidez jaso dutenak (B taldea). 1. taulan aukeratu ditugun aldagaien araberako informatzaile mota bakoitzaren kopuruak eta portzentajeak ematen ditugu. 


\begin{tabular}{|c|c|c|c|c|c|c|c|}
\hline \multicolumn{2}{|c|}{ Ama hizkuntza } & \multicolumn{2}{c|}{ A } & \multicolumn{2}{c|}{ B } & \multicolumn{2}{c|}{ Guztira } \\
\hline Mota & Generoa & kopurua & $\%$ & Kopurua & $\%$ & Kopurua & $\%$ \\
\hline \multirow{2}{*}{ Bat-batekoa } & neskak & 39 & 38,61 & 32 & 31,68 & 71 & 70,29 \\
\cline { 2 - 9 } & mutilak & 16 & 15,84 & 14 & 13,86 & 30 & 29,71 \\
\hline \multirow{2}{*}{ Irakurria } & neskak & 8 & 25 & 8 & 25 & 16 & 50 \\
\cline { 2 - 9 } & mutilak & 8 & 25 & 8 & 25 & 16 & 50 \\
\hline
\end{tabular}

1. Taula: Eduki ditugun informatzaile kopuruak eta portzentajeak esaldi mota bakoitzeko euron ama hizkuntzaren eta generoaren arabera sailkatuta.

Grabazio gehienak UPV/EHUko Bilboko Irakasleen Eskolan egin dira eta bakar batzuk informatzaileen herrietan. Erabili diren grabagailuak Sony minidisk, Zoom Hn4, Marantz eta ordenagailu eramangarria izan dira.

2. taulan bat-bateko esaldiak jasotzeko izan ditugun informatzaileen jatorrizko herriak adierazten dira; herriaren izenarekin batera informatzaileen ama hizkuntza adierazten da "A" (A taldea) eta "B" (B taldea) hizkien bidez eta generoa "n" (neska) eta "m" (mutila) hizkien bidez adierazten da (Ikusi 1. irudiko mapa).

AbadiñoAn, AbadiñoBn, AbantoBn, AlontsotegiBn, AmorotoAn, AreatzaAn, AreatzaAm, ArrankudiagaBn, ArratzuAn, ArrigorriagaBn, AulestiAn, AulestiAm, BakioAn, BalmasedaBn, BarakaldoBn, BarakaldoBm, BasauriBn, BasauriBm, BermeoAn, BermeoAm, BermeoBn, BerriatuaAn, BerrizAn, BerrizBm, BilboBn1, BilboBn2, BilboBn3, BilboBn4, BilboBn5, BilboBm1, BilboBm2, BilboBm3, DerioAn, DimaAn, DimaAm, DurangoAn, DurangoAm, DurangoBn, DurangoBm, EaAn, ElorrioAn, ElorrioBn, EreñoAn, ErmuaAn, EtxebarriaAn, GaldakaoAn, GaldakaoAm, GaldakaoBm, GernikaAn, GernikaAm, GernikaBn, GernikaBm, GetxoBn, GordexolaBn, GueñesBn, IgorreAn, IgorreAm, IgorreBn, IgorreBm, IspasterAn, KarrantzaBn, LarrabetzuAn, LarrabetzuAm, LeioaAn, LeioaBn, LekeitioAn, LekeitioAm, LemoaAn, LemoaAm, LezamaAn, MallabiaAn, MañariaAn, MarkinaAn, MarkinaAm, MorgaAn, MungiaAn, MungiaAm, MuxikaAn, OndarroaAn, OndarroaAm, OrozkoAn, PortugaleteBn, PirtugaleteBm, SanturtziBn, SestaoBn, SestaoBm, SondikaBn, SopelaAn, SopelaBn, TrapagaranBn, UgaoBn, UrdulizBm, ZaldibarAn, ZallaBn, ZallaBm, ZamudioBn, ZeanuriAn, ZierbenaBn, ZornotzaAn eta ZornotzaAm.

2. Taula: Bat-bateko esaldiak jasotzeko izan ditugun informatzaileen herriak. 


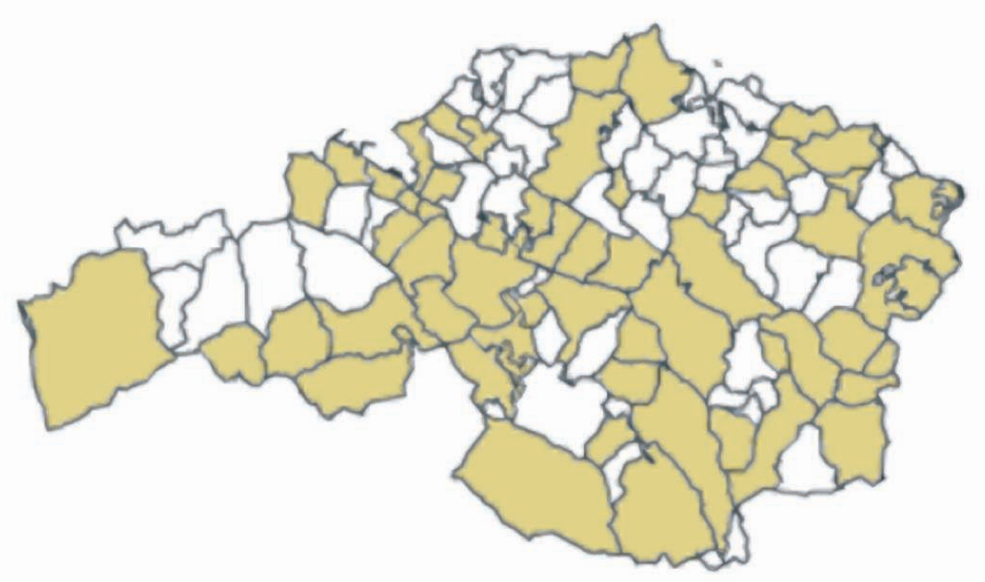

1. irudia: Bat-bateko esaldiak jasotzeko eduki ditugun informatzaileen herriak.

3. taulan gauza bera egiten dugu baina esaldi irakurriak jasotzeko izan ditugun informatzaileen herriekin (Ikusi 2. irudiko mapa)

AbadiñoAm, BarakaldoBn, BermeoAn, BerrizAn, BilboBn, BilboBm, DimaAm, DurangoBm, DurangoAn, GernikaAn, GetxoBm, IgorreAm, IurretaBn, LeioaAm, LeioaBn, LekeitioAn, LekeitioAm, LezamaAn, LezamaAm, MungiaAn, MungiaAm, PortugaleteBn, PirtugaleteBm, SanturtziBm1, SanturtziBm2, SestaoBm, SopelaBn, TrapagaranBm, ZallaBn, ZornotzaAn eta ZornotzaAm

3. Taula: Esaldi irakurriak jasotzeko izan ditugun informatzaileen herriak.

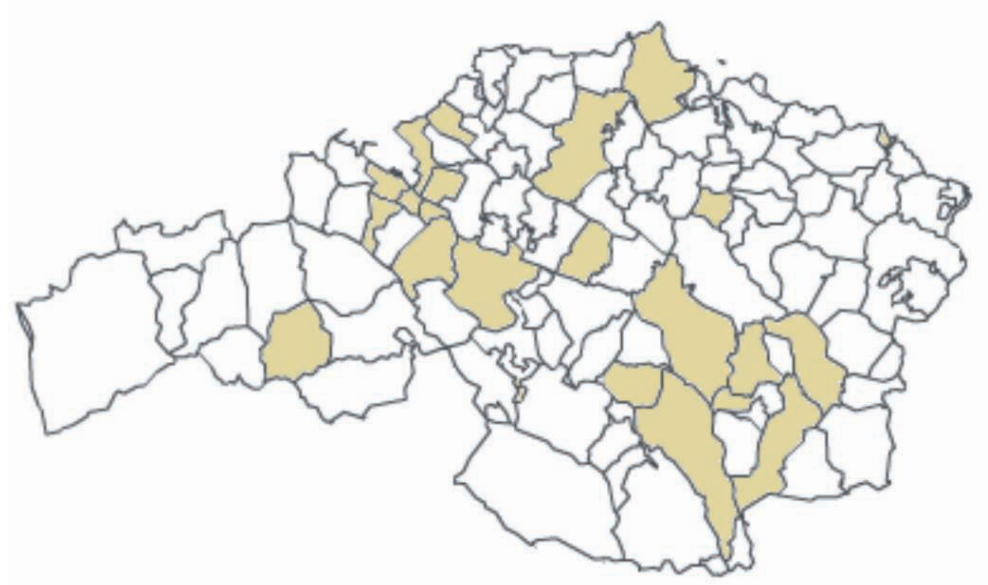

2. Irudia: Esaldi irakurriakak jasotzeko eduki ditugun informatzaileen herriak. 
Esaldiak jaso ondoren Praat programaren bidez (Boersma eta Weenink, 2014) aztertu dira. Behin transkripzio fonologikoa eginda kurbaren azterketa fonetikoaren bidez zein den esaldiaren muga-tonua erabaki da. 3. irudian transkripzio adibide bat erakusten da. Behin esaldi guztien transkripzioa eginez gero, datu basea osatu ahal izan da datuen gainerako azterketak burutzeko.

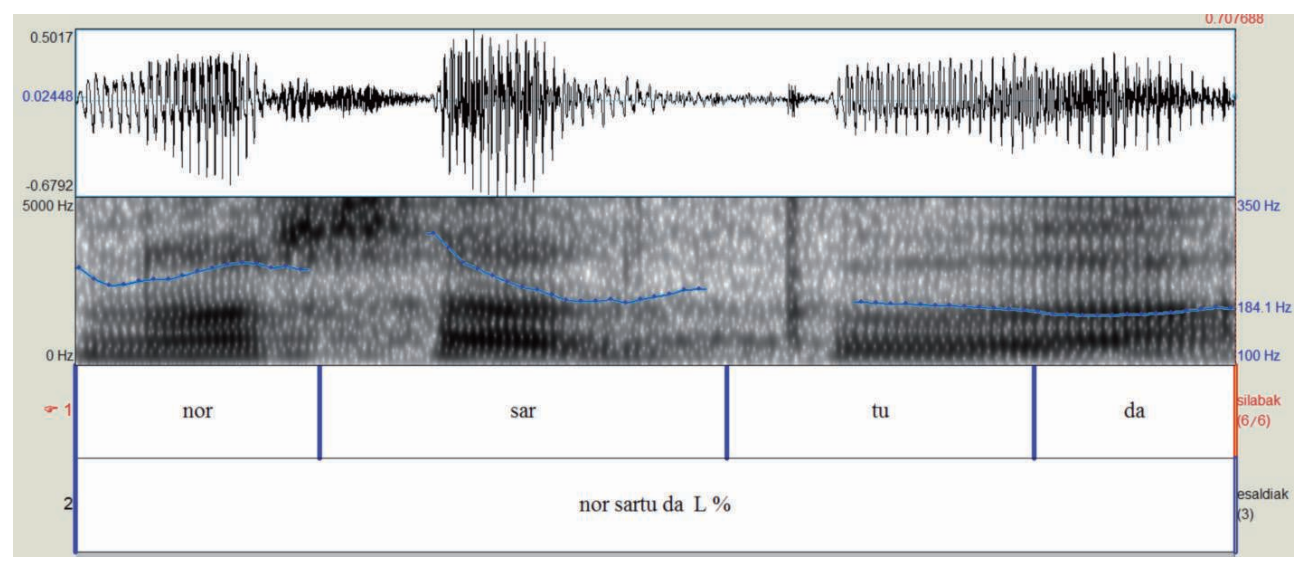

3. Irudia: «praat» programaren bidez egindako transkripzio adibidea eta azterketa fonetikoa egin ahal izateko aztertu den fo kurba (ElorrioAn).

\section{Datuen azterketa fonologikoa}

N/Z galderetan galdetzaileak eta aditzak osatutako esaldiak aztertu ditugu. 4. irudian ikusten den moduan, esaldi osoaren gailur prosodikoaren kokagunea galdetzailean bertan dago. Gailur horren ostean f0 apalduz doa azken silabaraino (kasu honetan behintzat).

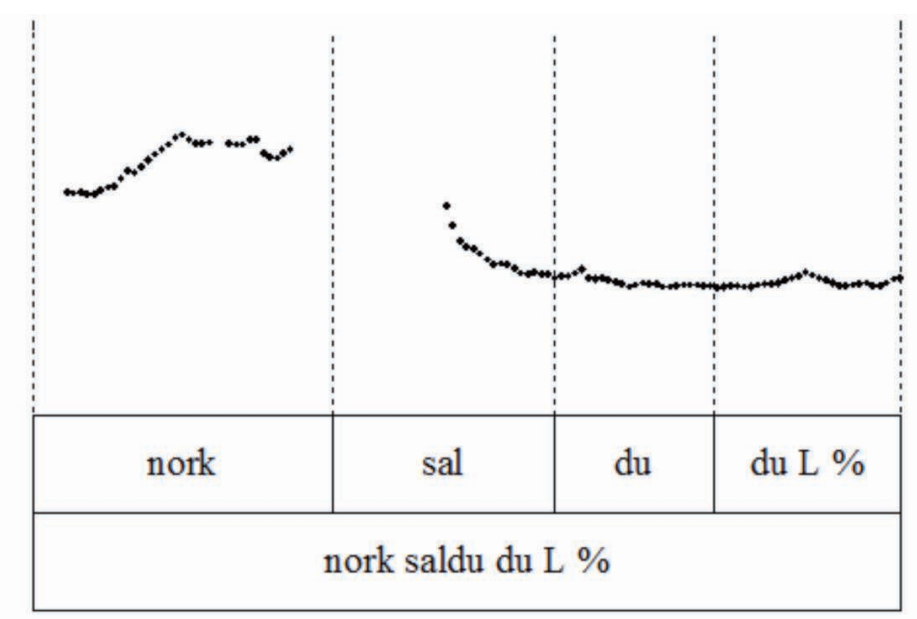

4. Irudia: N/Z galderaren gailur prosodikoaren kokagunea esaldiaren hasierako galdetzailean (ZallaBn). 
Orain arte egin diren lan batzuetan adierazi den moduan (Gaminde, 2007, 2010; Gaminde eta lag. 2014), esaldiaren amaieran f0ren apalaldia gertatzen izan da helduen belaunaldietan; berau fonologikoki ulertzeko esaldiaren L\% muga-tonua dagoela esan dezakegu. Lan horietan guztietan gazteek L\% muga-tonuaren ordez H\% muga-tonua erabiltzeko joera daukatela adierazten izan da ere bai.

Esaldien fo kurben azterketa fonetikoa egiten badugu, argi ikusten da ezen, azken silaban tonu igoera gertatzen den kasuetan mota bi bereiz daitezkeela. Batean, 5. irudian bezala, tonuak silaba osoan zehar gorantz egiten du; bestean, 6 . irudian bezala, azken silabaren zati batean tonuak apalduz segitzen du silabaren azken zatian gorantz egiteko, esaldi mota guztiak ez dira berdin berdinak izaten, kasu batzuetan igoera txiki bat gerta daiteke hasieran edo aurreko silabaren aldean maila berean euts dakioke tonuari, baina azken zatian goranzko igoera oso pika bihurtzen da.

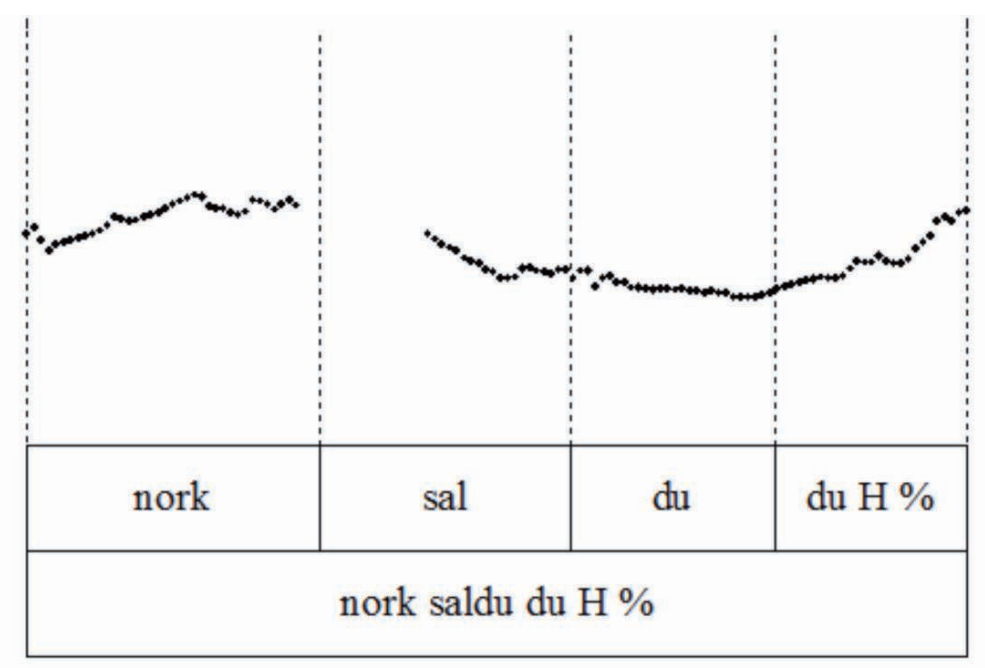

5. Irudia: N/Z galderaren H\% muga-tonua, tonuaren igoera silaba osoan zehar gertatzen da. (BarakaldoBn).

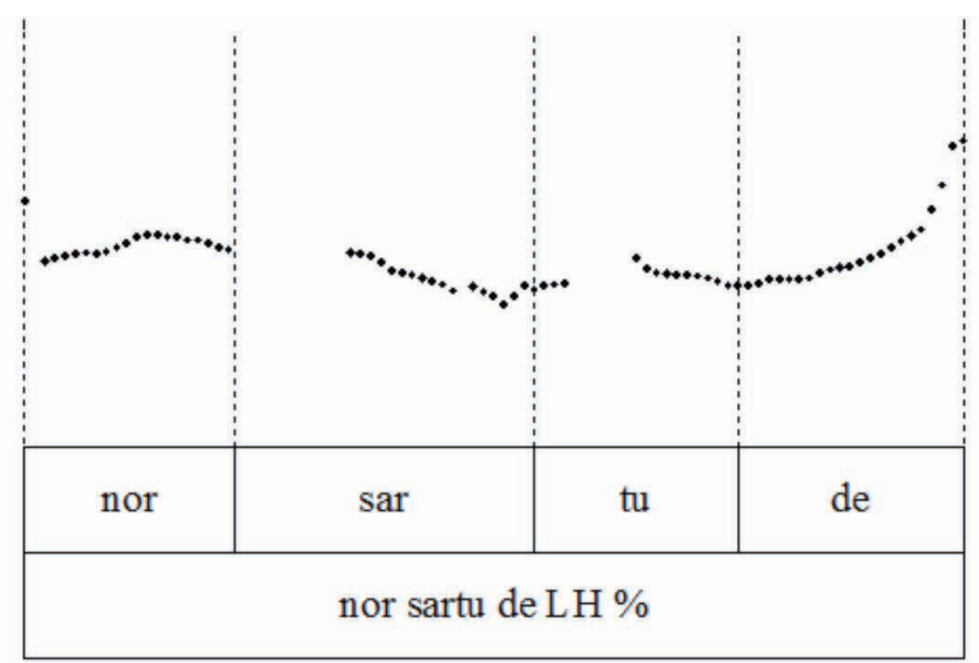

6. Irudia: Galderaren LH\% muga-tonua, tonuaren igoera azken silaba barruan gertatzen da (ZeanuriAn) 
Datu hauen arabera hiru muga-tonu mota bereiz ditzakegu esaldien amaieran, tonu horiek grafikoki erakusten dira 7. irudian.

(1) L \%: Beheranzko norabidean egiten den tonua.

(2) H\%: Goranzko norabidean egiten den tonua azken silaba osoan zehar.

(3) LH\%: Beheranzko-goranzko norabidean egiten den tonua.

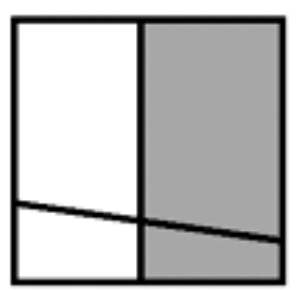

$\mathbf{L} \%$

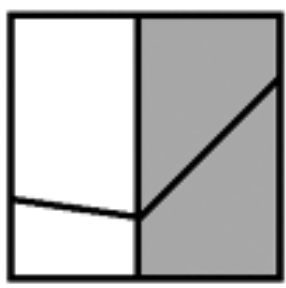

$\mathrm{H} \%$

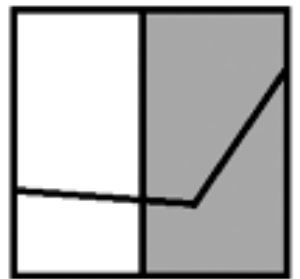

LH\%

7. Irudia: N/Z galderen muga-tonu mota bakoitza.

Hiru muga-tonu hauek bai bat-bateko esaldietan bai irakurrietan gertatzen dira. 4 . taulan bakoitzaren kopuruak eta portzentajeak ematen ditugu esaldi mota bakoitzaren arabera (8. irudiko grafikoa).

\begin{tabular}{|l|c|c|c|}
\hline & $\mathrm{L} \%$ & $\mathrm{LH} \%$ & $\mathrm{H} \%$ \\
\hline Bat-batekoa & 37,62 & 31,68 & 30,69 \\
\hline Irakurria & 15,63 & 31,25 & 53,13 \\
\hline \multicolumn{2}{|c|}{ 4. Taula: Muga-tonu bakoitzaren portzentajeak esaldi mota bakoitzaren arabera. } \\
\hline
\end{tabular}

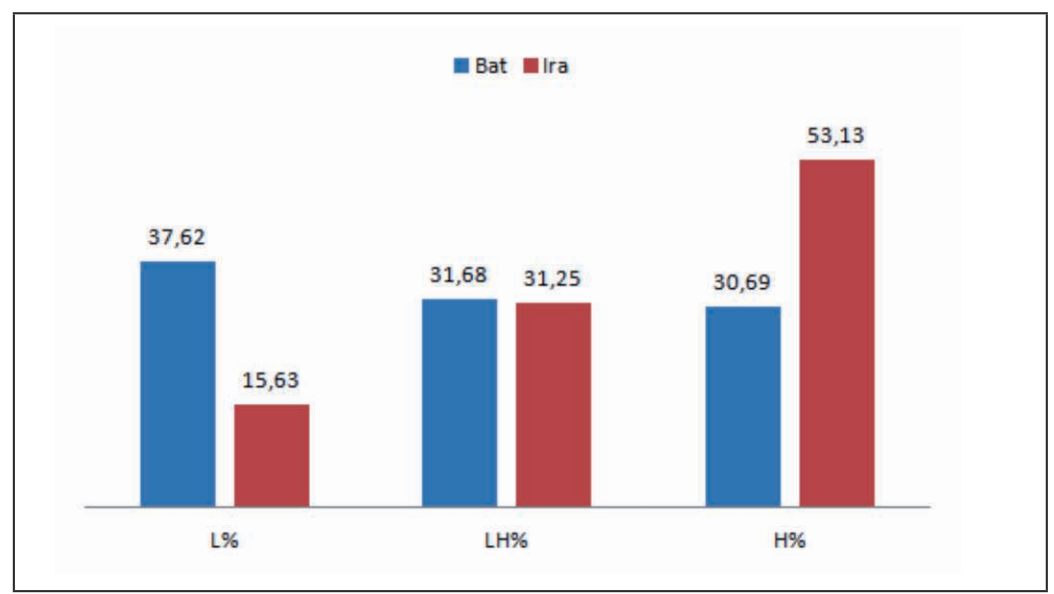

8. Irudia: Muga-tonu bakoitzaren portzentajeak esaldi moten arabera. 


\section{Bariazioaren azterketa}

Atal honetan aukeratu ditugu aldagaiek N/Z galderetan erabiltzen diren muga-tonuen agerpenetan eragina daukaten aztertuko dugu.

Dauzkagun datuak eskala nominalekoak izanik, estatistiko ez-parametrikoak erabili behar ditugu eta horretarako khi karratua aukeratu dugu $\left(\chi^{2}\right)$.

Datuak esaldi motaren arabera aztertzen baditugu, muga-tonuen portzentajeak 5 . taulan erakusten den moduan banatzen dira. Bertan ikusten den bezala, L\% eta H\% mugatonuekin alderik handienak gertatzen dira. Alde hauek estatistikoki esanguratsuak dira (khi = (2 a.m.) 7,027; p<0,031).

\begin{tabular}{|l|c|c|c|}
\hline & L\% & LH\% & H\% \\
\hline Bat-batekoa & 37,62 & 31,68 & 30,69 \\
\hline Irakurria & 15,63 & 31,25 & 53,13 \\
\hline \multicolumn{2}{|c|}{ 5. Taula: Muga-tonu bakoitzaren portzentajeak esaldi moten arabera. } \\
\hline
\end{tabular}

Datuak informatzaileen generoaren arabera aztertuta, 6. taulan agertzen diren portzentajeak lortzen ditugu (9. irudiko grafikoa) muga-tonu bakoitzeko. Bertan agertzen diren aldeak estatistikoki esanguratsuak dira (khi = (2 a.m.) 9,194; $\mathrm{p}<0,011)$.

\begin{tabular}{|l|c|c|c|}
\hline & L\% & LH\% & H\% \\
\hline mutilak & 43,48 & 15,22 & 41,30 \\
\hline neskak & 26,44 & 40,23 & 33,33 \\
\hline
\end{tabular}

6. Taula: Muga-tonu bakoitzaren portzentajeak informatzaileen generoaren arabera.

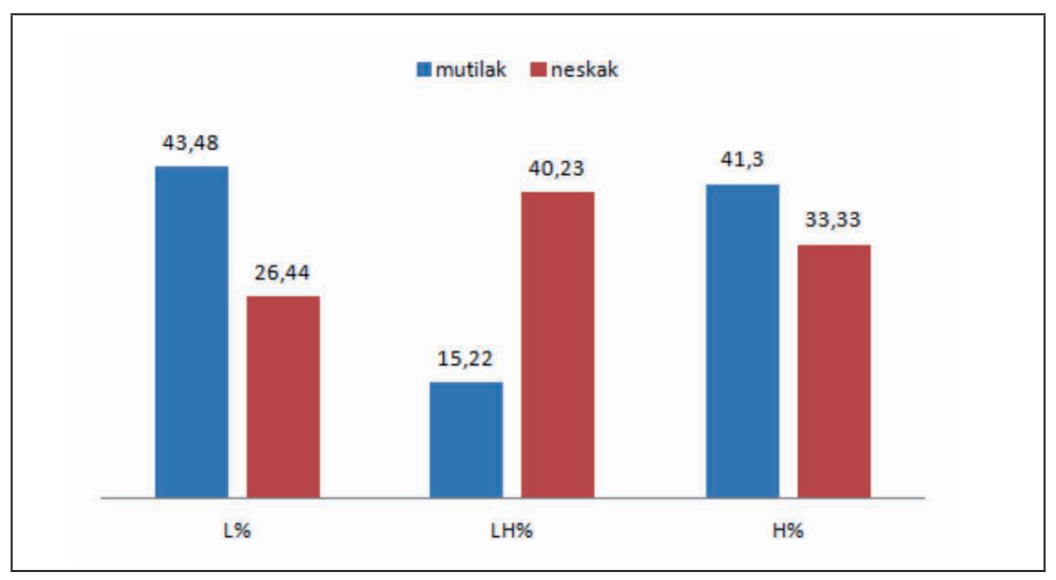

9. Irudia: Muga-tonu bakoitzaren portzentajeak informatzaileen generoaren arabera. 
Datuak informatzaileen ama hizkuntzaren arabera aztertuz gero, 7. taulan ikus daitezkeen portzentajeak lortzen dira muga-tonu bakoitzeko (10. irudiko grafikoa). Bertan ikusten den moduan, aldeak oso txikiak dira eta ez dira estatistikoki esanguratsuak (khi = (2 a.m.) 0,$617 ; \mathrm{p}<* 0,736)$.

\begin{tabular}{|l|c|c|c|}
\hline & L\% & LH\% & H\% \\
\hline A & 35,21 & 29,58 & 35,21 \\
\hline B & 29,03 & 33,87 & 37,10 \\
\hline \multicolumn{2}{|c|}{ 7. Taula: Muga-tonu bakoitzaren portzentajeak informatzaileen ama hizkuntzaren arabera } \\
sailkatuta.
\end{tabular}

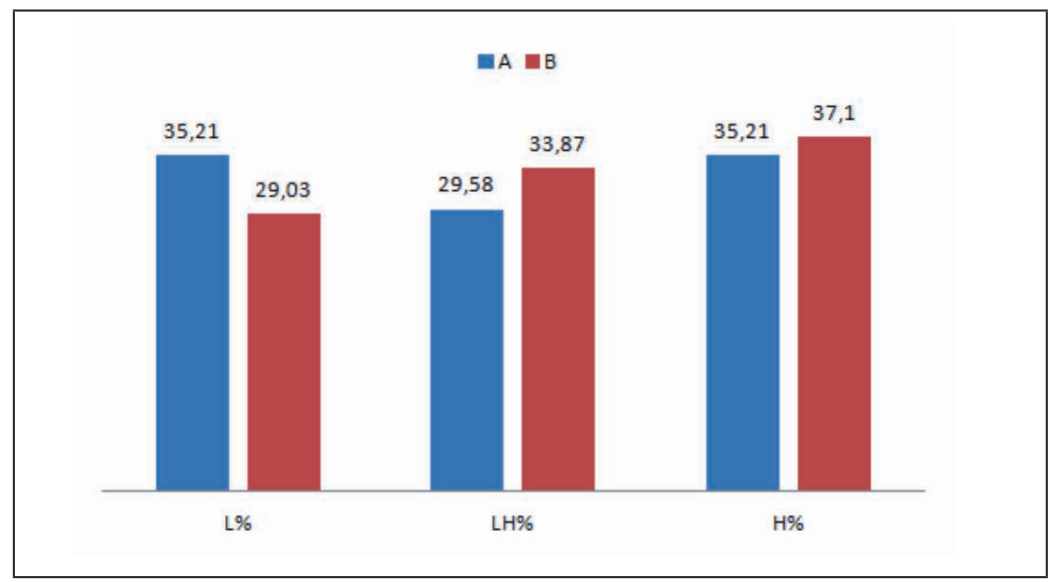

10. Irudia: Muga-tonu bakoitzaren portzentajeak informatzaileen ama hizkuntzaren arabera sailkatuta.

8. taulan muga-tonu bakoitzaren portzentajeak ematen ditugu esanguratsuak diren aldagai bien arabera (11. irudiko grafikoa).

\begin{tabular}{|c|c|c|c|c|}
\hline & & L\% & LH\% & H\% \\
\hline \multirow{3}{*}{ Bat-batekoa } & mutilak & 56,67 & 16,67 & 26,67 \\
\cline { 2 - 5 } & neskak & 29,58 & 38,03 & 32,39 \\
\hline \multirow{2}{*}{ Irakurria } & mutilak & 18,75 & 12,50 & 68,75 \\
\cline { 2 - 5 } & neskak & 12,50 & 50,00 & 37,50 \\
\hline
\end{tabular}

8. Taula: Muga-tonu bakoitzaren portzentajeak esaldi motaren eta informatzaileen generoaren arabera sailkatuta. 


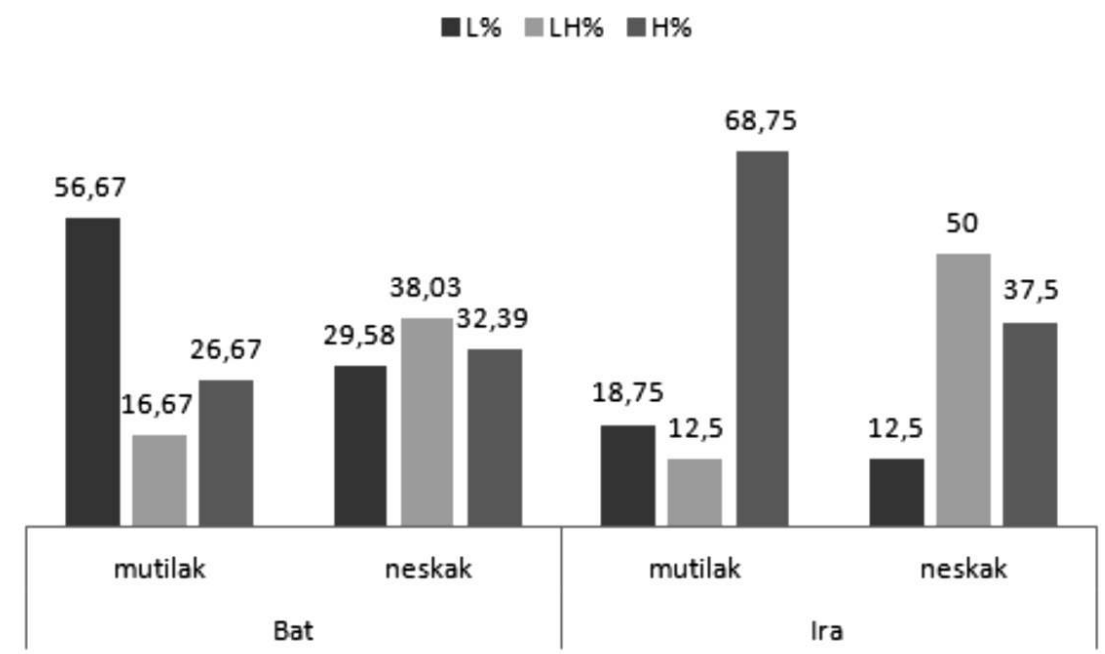

11. Irudia: Muga-tonu bakoitzaren portzentajeak esaldi motaren eta informatzaileen generoaren arabera sailkatuta.

Taulan agertzen diren generoaren araberako aldeak estatistikoki esanguratsuak dira esaldiak bat-batekoak direnean (khi $(2$ a.m.) = 8,044; p <0,019) ez, ostera, esaldi irakurriekin (khi $(2$ a.m.) $=2,008 ; \mathrm{p}<0,367)$.

\section{Ondorioak}

Lan honetako ondorio nagusiak multzo bitan bana daitezke; batetik azterketa fonologikoari dagozkionak ditugu eta, bestetik, bariazioari dagozkionak.

Ikusi dugun moduan, azterketa fonetikoan oinarritutako muga-tonuen inbentario fonologikoan hiru muga-tonu proposatu behar dira: L\%, LH\% eta $\mathrm{H} \%$.

Bariazio azterketan argi agertu zaigu esaldi motak eragin handia daukala mugatonuen erabileran; horrela bada, L\% muga-tonua askozaz gehiagotan erabiltzen da bat-bateko esaldietan irakurrietan baino. Era berean, H\% muga-tonua gehiagotan agertzen da esaldi irakurrietan bat-batekoetan baino. LH\% muga-tonuari dagokionez, ez dago alde handirik. Datu hauek inplikazio didaktiko zehatzak dauzkate, izan ere, esaldiak irakurtzen direnean beste molde bat erabiltzeko joera azkarra dago. Honek, neurri handi batean, adierazten du informatzaileek ez dutela irakurketa ozena landu edo landu dutenean, arazo honi ez zaiola behar besteko garrantzia eman.

Oso adierazgarria da, bestalde, informatzaileen ama hizkuntzak eraginik ez edukitzea muga-tonuen erabileran. Haatik, generoak badu eragina erabileran, ikusi dugun moduan, neskek askoz gutxiagotan erabiltzen dute L\% tonua mutilek baino eta LH\% gehiagotan erabiltzen dute mutilek baino.

Gorago esaneko moduan, tradizioari jarraikirik, N/Z galderen muga-tonu nagusia L\% izan bada, argi ikusten dugu gaurko joera bestelakoa dena, eta esaldi irakurrietan askoz handiagoa L\% muga-tonua ez erabiltzeko bat-bateko esaldietan baino. Beste inon iradoki dugun moduan (Gaminde eta lag., 2014), esku hartze didaktiko zehatza egin beharko litzateke joera hau zuzentzekotan. 


\section{Erreferentziak}

Aurrekoetxea, Gotzon \& Iñaki Gaminde (koor.). 2011. Prosodiaz eta Hezkuntzaz I. Jardunaldiak / I. Jornadas sobre Prosodia y Educación. Bilbo: UPV-EHU.

Aurrekoetxea, Gotzon, Iñaki Gaminde \& Aitor Iglesias. 2011. Corpusbased prosodic variation in basque: Y/N questions marked with the particle al. Estudios de Fonética Experimetal XX. 11-31

Boersma, Paul \& David Weenink. 2014. Praat: doing phonetics by computer 5402 bertsioa. [Computer program] http://www.praat.org

Elordieta, Gorka. 1997. Accent, tone, and intonation in Lekeitio Basque. In Fernando Martínez-Gil \& Alfonso Morales-Front (eds.), Issues in the Phonology and Morphology of the Major Iberian Languages, 3-78. Washington (DC): Georgetown University Press.

Elordieta, Gorka. 1999. Primer estudio comparativo de la entonación de tres variedades dialectales vascas. Actas del I Congreso de Fonética Experimental. 22-24. Universitat Rovira i Virgili \& Universitat de Barcelona.

Elordieta, Gorka. 2000. Mendebaldeko intonazioaren inguruan. Mendebalde Kultura Alkartea (arg.), Mendebaldeko berbetearen formalizazinoa, 111-156. Bilbo: Mendebalde Kultura Alkartea.

Elordieta, Gorka. 2003. Intonation. In José Ignacio Hualde \& Jon Ortiz de Urbina (arg.), A grammar of Basque, 72-113. Mouton de Gruyter: Berlin.

Elordieta, Gorka. 2008. Euskal azentu eta intonazioari buruzko ikerketa: status quaestionis.<http:// www.elebilab.com/documentos/archivos/publicaciones/Elordieta-Koldo\%20Mitxelena\% 20Katedrarako.pdf>

Gaminde, Iñaki. 2007. Bizkaian zehar. Euskararen ikuspegi orokorra. Mendebalde Kultura Alkartea: Bilbo.

Gaminde, Iñaki. 2010, Bizkaiko gazteen prosodiaz: euskaraz eta gaztelaniaz. Mendebalde Kultura Alkartea eta BFA: Bilbo.

Gaminde, Iñaki \& Udane Goikoetxea. 2005. Irakurketa Ebaluatzeko Irizpideak Bizkaian. Bilbo: Mendebalde Kultura Alkartea.

Gaminde, Iñaki, Asier Romero \& Hiart Legarra. 2012. Gramatika eta Hizkuntz Bariazioa Bermeon. Bermeo: Bermeoko Udala eta Campos Hegaluzea.

Gaminde, Iñaki, Gotzon Aurrekoetxea, Aintzane Etxebarria, Urtza Garay \& Asier Romero. 2014. Ahoskera Lantzeko Argibideak eta Jarduerak. Laguntzarako materiala: Teoria eta Praktika. Bilbo: UPV/EHU.

Gandarias, Rosa. 1996. Ispasterko Intonazioaren Deskribapena: Azterketa Fonetikoa. Doktorego Tesia, UPV/EHU.

Hualde, José Ignacio. 2003. El modelo métrico y autosegmental. In Pilar Prieto (koor.), Teorías de la Entonación, 155-184. Bartzelona: Ariel.

Hualde, José Ignacio \& Jon Ortiz de Urbina. 2003. A Grammar of Basque. Berlin \& New York: Mouton de Gruyter.

Jun, Sun-Ah \& Gorka Elordieta. 1997. Intonational Structure of Lekeitio Basque. In Antonis Botinis, Georgios Kouroupetroglou \& George Carayiannis (arg.), Intonation: Theory, Models and Applications, Proceedings of an ESCA Workshop. 193-196. ESCA: Atenas.

Legarra, Hiart. 2011. Muxikako euskararen azterketa linguistikoa. Doktorego Tesia, Deustuko Unibertsitatea.

Uriarte, Jon Andoni. 1995. Fruizko Hizkera: Azterketa Linguistikoa. Doktorego Tesia, Deustuko Unibertsitatea. 